\title{
Study of Fibro Q Index as a Non invasive Method to Predict Liver Fibrosis in Chronic Hepatitis C
}

Mohammed A Nouh ${ }^{1}$, Hatem M El Sebaey ${ }^{2}$, Somaia A Shehab El-Deen ${ }^{1}$,Sherif AA Allam ${ }^{3}$

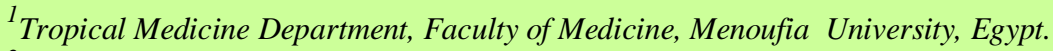

${ }^{2}$ Medical Biochemistry Department, Faculty of Medicine, Menoufia University, Egypt.

${ }^{3}$ Tanta Fever Hospital, Tanta ,Egypt.

\section{Corresponding}

Author:

Sherif Abd El-Aziz Abd

El-Fatah Allam

Mobile:

0201224148649

E mail:

sherifallam 389

@yahoo.com

Key words: Liver fibrosis; FibroQ; FIB-4 index; Lok's model; Cirrhosis discriminant score; Pohl score.
Background and study aim : Monitoring of liver fibrosis progression is important in patients with chronic hepatitis $\mathrm{C}$. The aim of this study is to verify the usefulness of FibroQ for predicting fibrosis in patients with chronic hepatitis C compared with other noninvasive tests.

Patients and methods: This study included 90 naïve patients with chronic hepatitis $\mathrm{C}$ who had undergone percutaneous liver biopsy before treatment and 20 healthy volunteers as a control group. FibroQ, aspartate aminotransferase (AST)/alanine amino-transferase ratio (AAR), AST to platelet ratio index, cirrhosis discriminates score, age-platelet index (API), Pohl score, FIB-4 index, and Lok's model were calculated and compared.

Results: FibroQ, FIB-4, AAR, API and Lok's model results increased significantly as fibrosis advanced .FibroQ trended to be superior in predicting significant fibrosis score in chronic hepatitis $\mathrm{C}$ compared with other noninvasive tests.

Conclusion: FibroQ is a simple and useful test for predicting significant fibrosis in patients with chronic hepatitis $\mathrm{C}$.

\section{INTRODUCTION}

Chronic hepatitis $\mathrm{C}$ virus (HCV) infection is a major health problem affecting more than 170 million people worldwide. It is associated with a high risk of development of cirrhosis and hepatocellular carcinoma [1]. HCV infection and its complications represent a major health problem in Egypt, where 10\%-15\% (about 9 million) of the general population is infected [2]. Hepatitis $\mathrm{C}$ infection is characterized by high rates of chronicity as about $70-85 \%$ of acute HCV cases progress to chronic hepatitis [3]. About 20\% of chronically infected patients develop liver fibrosis and cirrhosis with subsequent progression to end stage liver disease or hepatocellular carcinoma [4]. Monitoring of liver fibrosis progression is important in patients with chronic hepatitis $\mathrm{C}$ because it allows screening for $\mathrm{HCC}$ and also these patients have the most urgent need for antiviral therapy [5]. Liver biopsy is recommended before starting antiviral treatment, but it has many problems as it is expensive, requires an experienced clinician, and may cause complications, including mortality in $0.018 \%$ of patients(6). In addition, sampling errors and observer variations may lead to under-staging of cirrhosis, particularly macronodular cirrhosis [7]. Several noninvasive tests have been proposed to assess the severity of hepatic fibrosis as an alternative to liver biopsy. As reported by Akkayaet al. [8], there is correlation between alanine aminotransferase (ALT) levels in patients with hepatitis $\mathrm{C}$ virus (HCV) infection and periportal bridging/ necrosis, and Lu et al. [9] have reported that patients with cirrhosis have thrombocytopenia. Also, aspartate aminotransferase (AST)-to-platelet ratio index (APRI) [10] and AST/ ALT ratio (AAR) [11], cirrhosis discriminant score (CDS) [12], age-platelet index (API) [13], Pohl score [14], FIB-4 index [15], and Lok's model [16] are well-known non invasive parameters that are based on routine laboratory data, and are so readily available in clinical practice. These parameters have been reported to predict the 
presence of significant fibrosis and extensive fibrosis in some patients [8-17]. Hsieh et al. [17] proposed Fibro Q index, which equals $10 \times$ (age $\times \mathrm{AST} \times \mathrm{PT}-\mathrm{INR}) /(\mathrm{ALT} \times$ platelet count $)$ to predict significant fibrosis. The aim of the present study is to verify the usefulness of Fibro Q for predicting fibrosis in patients with chronic hepatitis $\mathrm{C}$ compared with other non-invasive tests.

\section{PAIENTS AND METHODS}

A total number of 90 naïve patients with chronic $\mathrm{HCV}$ were selected from 120 patients referred to Tanta Fever Hospital (Interferon Unit) in the period between July 2013 and February 2014. They were 54 males (60\%) and 36 females (40\%) and their ages were ranging from 24-58 years with a mean value of 40.9 years \pm 7.5 years as well as 20 volunteers as a control group. An informed consent was obtained before patients enter the study. Diagnosis of chronic hepatitis C was confirmed by the presence of anti-HCV antibody by enzyme immunoassay methods more than 6 months and the presence of HCV-RNA by polymerase chain reaction Subjects were categorized into 2 main groups, Group I (90 patients with CHC) and Group II (healthy control volunteers ; 20 patients). Thirty Patients with the following conditions were excluded from the study: those co-infected with human immunodeficiency virus or HBV, and those with alcohol consumption in excess of $20 \mathrm{~g} / \mathrm{d}$, hepatocellular carcinoma, liver transplantation, antiviral or immunosuppressive therapy, metabolic liver disease, insufficient liver tissue for fibrosis staging, or recent warfarin or other anticoagulant usage. Patients and Controls were subjected to thorough history taking, full clinical examination (General and local examination), abdominal ultrasonography (U/S), laboratory investigations (liver function tests, $\mathrm{CBC}$, renal function tests, thyroid function tests, $\mathrm{HCV}$ antibody by ELIZA, Detection of HCV-RNA by PCR, shistosomal antibody by ELIZA, Serum Alpha feto-protein), Liver biopsy, calculation of FibroQ index, AAR, APRI, CDS, API, FIB4index, Pohl score and Lok's model.

\begin{tabular}{|c|c|}
\hline $\begin{array}{c}\text { Fibrosis } \\
\text { test }\end{array}$ & Calculation \\
\hline AAR & AST/ALT \\
\hline APRI & {$\left[(\mathrm{AST} / \mathrm{ULN}) /\right.$ platelet count $\left.\left(10^{9} / \mathrm{L}\right)\right] \times 100$} \\
\hline CDS & $\begin{array}{l}\text { CDS is the sum of the following: (possible } \\
\text { value, } 0-11 \text { ) } \\
\text { Platelet count }(109 / \mathrm{L}):>340=0 ; 280-339=1 ; \\
220-279=2 ; 160-219=3 ; 100-159=4 ; 40-99 \\
=5 ;<40=6 \\
\text { ALT/AST ratio: }>1.7=0 ; 1.2-1.7=1 ; 0.6- \\
1.19=2 ;<0.6=3 \\
\text { INR: }<1.1=0 ; 1.1-1.4=1 ;>1.4=2\end{array}$ \\
\hline API & $\begin{array}{l}\text { calculated by summing the scores awarded for } \\
\text { the following patient laboratory results }(\text { a } \\
\text { possible value of } 0-10): \text { age }(\text { in years })<30= \\
0 ; 30-39=1 ; 40-49=2 ; 50-59=3 ; 60-69=4 ; \\
\geq 70=5 ; \text { platelet count }(\times 109 / \mathrm{L}): \geq 225=0 ; \\
200-224=1 ; 175-199=2 ; 150-174=3 ; 125- \\
149=4 ;<125=5 ;\end{array}$ \\
\hline $\begin{array}{l}\text { Pohl } \\
\text { score }\end{array}$ & $\begin{array}{l}\text { It is considered positive if: AAR } \geq 1 \text { and } \\
\text { platelet count }<150 \times 10^{9} / \mathrm{L}\end{array}$ \\
\hline $\begin{array}{l}\text { FIB-4 } \\
\text { index }\end{array}$ & $\begin{array}{l}{[\text { Age }(\mathrm{yr}) \times \operatorname{AST}(\mathrm{U} / \mathrm{L})] /\left[\text { platelet count }\left(10^{9} / \mathrm{L}\right)\right.} \\
\times \operatorname{ALT}(\mathrm{U} / \mathrm{L}) 1 / 2]\end{array}$ \\
\hline $\begin{array}{l}\text { Lok's } \\
\text { model }\end{array}$ & $\begin{array}{l}\text { Log odds (predicting cirrhosis })=-5.56 \text { to } \\
0.0089 \times \text { platelet }\left(\times 10^{3} / \mathrm{mm}^{3}\right)+1.26 \times \\
\text { AST/ALT ratio }+5.27 \times \mathrm{PT} \text { INR } \\
\text { Predicted probability }=\exp (\log \text { odds }) /[1+\exp \\
(\log \text { odds })]\end{array}$ \\
\hline
\end{tabular}

AST: Aspartate aminotransferase; ALT: Alanine aminotransferase; AAR: AST/ALT ratio; APRI: AST-toplatelet ratio index; API: Age-platelet index; CDS: Cirrhosis discriminate score; ULN: Upper limit of normal; PT-INR: Prothrombin time- international normalized ratio.

\section{Statistical analysis}

Statistical analysis was performed using SPSS software version 20. Patient characteristics were represented as the mean $\pm \mathrm{SD}$. Bivariate Spearman's rank correlation coefficient ( $\mathrm{r} s$ ) was calculated to measure the relationship between the clinical variables and degree of fibrosis. To evaluate the diagnostic accuracies of the simple fibrosis prediction tests, their sensitivity, specificity, positive predictive value (PPV), negative predictive value (NPV) were done. In tests of significance, two-sided $\mathrm{P}<0.05$ was considered significant.

\section{RESULTS}

There were no statistical significant differences between studied groups as regard age and sex as shown in table (1). There were significant differences between the studied groups as regard AST, ALT, Alkaline phosphatase and prothrombin time and no significant differences between the studied groups as regard serum albumin, prothrombin activity, INR, total bilirubin and direct bilirubin as shown in table (2). There were 
significant differences between the studied groups as regard $\mathrm{HB} \%$, RBCS, mean platelet volume (mpv) and platelet count and no significant differences between the studied groups as regard WBCS as shown in table (3). No significant differences were present between the studied groups as regard urea and creatinine as shown in table (4). There were significant differences between the studied groups as regard ANA titer and no significant differences between the studied groups as regard Schistosomal AB, TSH, Alpha feto-protein and random blood sugars shown in table (5). There were significant differences between the studied groups as regard APRI, CDS, FIB-4 index Fibro Q index and Pohl score and no significant differences between the studied groups as regard AAR and API as shown in table (6). There were positive correlation between Fibro Q and sex, age, AST, INR, AAR, APRI, API, CDS, FIB4 index, alkaline phosphatase, prothrombin activity, ANA titer by ELIZA, Schistosomal AB by ELIZA, HCV-RNA level (PCR),HB\%, Random blood sugar, creatinine, total bilirubin and direct bilirubin and negative correlation between Fibro Q and ALT, platelets, Pohl score, serum albumin, prothrombin time and activity, Alpha feto-protein, TSH, RBCS,WBCS, mean platelet volume and urea as shown in table (7).There were 10 cases with F1 (11.1\%), 54 cases with F2 (60\%), 22 cases with F3 (24.4\%) and 4 cases with F4 (4.4) as shown in table (8). The highest correlation was observed for Fibro Q ( $r s=0.435)$, Lok's model ( $r s=$ $0.426)$, FIB-4 ( $r s=0.426)$, API $(0.323)$ and Pohl score (0.112) as shown in (Table 9). AAR, FibroQ, FIB-4, API, and Lok's model results increased significantly as the fibrosis advanced as shown in (table 10). For the prediction of mild fibrosis (F1 and F2); using a cutoff value of the Fibro Q score of $>1.4$ to predict the presence of significant fibrosis resulted in a sensitivity of $86 \%$, specificity of $79.6 \%$, PPV of $75.4 \%$, and NPV of $90.6 \%$. With AAR, the cut-off levels to predict the presence (AAR >2.4) of significant fibrosis had a sensitivity of $77.4 \%$ specificity of $63.6 \%$, PPV of $72.6 \%$, and NPV of $89.6 \%$. Using APRI, the cutoff values to predict the presence (APRI >1.5) of significant fibrosis had a sensitivity of $77.6 \%$, specificity of $81.6 \%$, PPV of $72.6 \%$, and NPV of $84.6 \%$ (Table 11). For the prediction of extensive fibrosis (F3 and F4), at a cutoff of Fibro Q > 2.6 the sensitivity was $84.9 \%$, specificity was79.6\%, PPV was $68.7 \%$ and NPV was $78.3 \%$ and at a cutoff of FIB-4 $>2.4$, the sensitivity was $89.4 \%$, specificity was $57.4 \%$, PPV was $71.6 \%$ and NPV was $80.4 \%$ (Table 12).

Table (1): Comparison between the studied groups as regard age and sex

\begin{tabular}{|c|c|c|c|c|c|c|c|}
\hline & & & $\begin{array}{l}\text { p I } \\
\text { nts) }\end{array}$ & & $\begin{array}{l}\text { p II } \\
\text { rol) }\end{array}$ & $\begin{array}{l}\text { t. test } \\
\text { or } X^{2}\end{array}$ & p. value \\
\hline \multirow{2}{*}{ Age } & Range & \multicolumn{2}{|c|}{$24-58$} & \multicolumn{2}{|c|}{$27-49$} & \multirow{2}{*}{1.326} & \multirow{2}{*}{0.245} \\
\hline & Mean + SD & \multicolumn{2}{|c|}{$40.9 \pm 7.5$} & \multicolumn{2}{|c|}{$37.7 \pm 6.3$} & & \\
\hline & & $\overline{\mathbf{N}}$ & $\%$ & $\mathbf{N}$ & $\%$ & & \\
\hline \multirow{3}{*}{ Sex } & Male & 54 & 60 & 13 & 65 & \multirow{3}{*}{0.465} & \multirow{3}{*}{0.528} \\
\hline & Female & 36 & 40 & 7 & 35 & & \\
\hline & Total & 90 & 100 & 20 & 100 & & \\
\hline
\end{tabular}


Table (2): Comparison between the studied groups as regard liver function tests

\begin{tabular}{|c|c|c|c|c|c|}
\hline & & $\begin{array}{c}\text { Group I } \\
\text { (Patients) }\end{array}$ & $\begin{array}{l}\text { Group II } \\
\text { (Control) }\end{array}$ & t. test & P. value \\
\hline \multirow{2}{*}{ AST (SGOT) } & Range & $14-96$ & $17-31$ & \multirow{2}{*}{9.362} & \multirow{2}{*}{$0.001 *$} \\
\hline & Mean + SD & $38.3 \pm 16.9$ & $24.6 \pm 4.35$ & & \\
\hline \multirow{2}{*}{ ALT (SGPT) } & Range & $13-202$ & $23-36$ & \multirow{2}{*}{3.256} & \multirow{2}{*}{$0.010 *$} \\
\hline & Mean + SD & $49.56 \pm 12.3$ & $30.2+3.86$ & & \\
\hline \multirow{2}{*}{ Alkaline phosphatase } & Range & $10-255$ & $42-430$ & \multirow{2}{*}{11.241} & \multirow{2}{*}{$0.001 *$} \\
\hline & Mean \pm SD & $85.5 \pm 11.36$ & $133.1 \pm 86.1$ & & \\
\hline \multirow{2}{*}{ Serum albumin } & Range & $3.4-5.1$ & $3.7-5.1$ & \multirow{2}{*}{0.635} & \multirow{2}{*}{0.253} \\
\hline & Mean \pm SD & $4.42 \pm 0.36$ & $4.34 \pm 0.39$ & & \\
\hline \multirow{2}{*}{$\begin{array}{l}\text { Prothrombin time and } \\
\text { control }\end{array}$} & Range & $12.1-13.6$ & $12.1-13.9$ & \multirow{2}{*}{2.336} & \multirow{2}{*}{$0.044 *$} \\
\hline & Mean \pm SD & $87.3 \pm 7.81$ & $86.7 \pm 8.14$ & & \\
\hline \multirow{2}{*}{ Prothrombin activity } & Range & $72-98$ & $72-98$ & \multirow{2}{*}{0.529} & \multirow{2}{*}{0.253} \\
\hline & Mean \pm SD & $87.3 \pm 7.8$ & $86.7 \pm 8.1$ & & \\
\hline \multirow{2}{*}{ INR } & Range & $1-1.3$ & $1-1.3$ & \multirow{2}{*}{1.252} & \multirow{2}{*}{0.253} \\
\hline & Mean + SD & $1.14+0.10$ & $1.14+0.09$ & & \\
\hline \multirow{2}{*}{ Total bilirubin } & Range & $0.24-1.3$ & $0.3-1.1$ & \multirow{2}{*}{0.417} & \multirow{2}{*}{0.635} \\
\hline & Mean \pm SD & $0.62 \pm 0.23$ & $0.62 \pm 0.25$ & & \\
\hline \multirow{2}{*}{ Direct bilirubin } & Range & $0.1-0.53$ & $0.03-0.52$ & \multirow{2}{*}{0.224} & \multirow{2}{*}{0.417} \\
\hline & Mean \pm SD & $0.22 \pm 0.08$ & $0.22 \pm 0.14$ & & \\
\hline
\end{tabular}

Table (3): Comparison between the studied groups as regard CBC

\begin{tabular}{|c|c|c|c|c|c|}
\hline & & $\begin{array}{c}\text { Group I } \\
\text { (Patients) }\end{array}$ & $\begin{array}{l}\text { Group II } \\
\text { (Control) }\end{array}$ & t. test & P. value \\
\hline \multirow{2}{*}{$\mathrm{HB} \%$} & Range & $9.3-17.6$ & $11.5-15.7$ & \multirow{2}{*}{4.326} & \multirow{2}{*}{$0.024 *$} \\
\hline & Mean \pm SD & $14.2 \pm 1.54$ & $13.35 \pm 1.57$ & & \\
\hline \multirow{2}{*}{ RBCS } & Range & $4-6.83$ & $4-5.5$ & \multirow{2}{*}{3.526} & \multirow{2}{*}{$0.036^{*}$} \\
\hline & Mean \pm SD & $5.24 \pm 0.50$ & $4.75 \pm 0.50$ & & \\
\hline \multirow{2}{*}{ WBCS } & Range & $3.3-13.3$ & $4.6-10.6$ & \multirow{2}{*}{0.241} & \multirow{2}{*}{0.256} \\
\hline & Mean \pm SD & $6.98+1.90$ & $7.01+1.43$ & & \\
\hline \multirow{2}{*}{$\begin{array}{c}\text { Mean platelet volume } \\
(\mathrm{mpv})\end{array}$} & Range & $5.3-15.3$ & $6.8-10.7$ & \multirow{2}{*}{4.225} & \multirow{2}{*}{$0.010 *$} \\
\hline & Mean \pm SD & $9.27 \pm 1.50$ & $8.44 \pm 1.09$ & & \\
\hline \multirow{2}{*}{ Platelets } & Range & $81-398$ & $220-400$ & \multirow{2}{*}{8.632} & \multirow{2}{*}{$0.001 *$} \\
\hline & Mean \pm SD & $223.4 \pm 60.4$ & $295.3 \pm 48.8$ & & \\
\hline
\end{tabular}

Table (4): Comparison between the studied groups as regard renal function tests

\begin{tabular}{|c|c|c|c|c|c|}
\hline \multicolumn{2}{|c|}{} & $\begin{array}{c}\text { Group I } \\
\text { (Patients) }\end{array}$ & $\begin{array}{c}\text { Group II } \\
\text { (Control) }\end{array}$ & \multirow{2}{*}{ t. test } & \multirow{2}{*}{ P. value } \\
\hline \multirow{2}{*}{ Creatinine } & Range & $0.37-1.18$ & $0.7-1.1$ & \multirow{2}{*}{1.325} & \multirow{2}{*}{0.552} \\
\cline { 2 - 4 } & Mean \pm SD & $0.83 \pm 0.14$ & $0.90 \pm 0.11$ & & \multirow{2}{*}{0.471} \\
\hline \multirow{2}{*}{ Urea } & Range & $16-33$ & $17-30$ & 0.141 \\
\cline { 2 - 4 } & Mean \pm SD & $24.8 \pm 4.7$ & $22.15 \pm 4.22$ & 1.47 \\
\hline
\end{tabular}


Table (5): Comparison between the studied groups as regard ANA titer, Schistosomal Ab, TSH, Alpha feto-protein and random blood sugar

\begin{tabular}{|c|c|c|c|c|c|}
\hline & & $\begin{array}{c}\text { Group I } \\
\text { (Patients) }\end{array}$ & $\begin{array}{l}\text { Group II } \\
\text { (Control) }\end{array}$ & t. test & P. value \\
\hline \multirow{2}{*}{ ANA titer by ELIZA } & Range & $4.8-13.8$ & $5.1-12.6$ & \multirow{2}{*}{3.589} & \multirow{2}{*}{$0.020^{*}$} \\
\hline & Mean \pm SD & $9.53 \pm 2.44$ & $8.05 \pm 2.24$ & & \\
\hline \multirow{2}{*}{$\begin{array}{c}\text { Schistosomal AB by } \\
\text { ELIZA }\end{array}$} & Range & $4.1-29.1$ & $4.1-29.1$ & \multirow{2}{*}{0.417} & \multirow{2}{*}{0.658} \\
\hline & Mean + SD & $17.54+9.49$ & $16.41+10.2$ & & \\
\hline \multirow{2}{*}{ TSH } & Range & $0.46-132$ & $0.39-3.25$ & \multirow{2}{*}{1.635} & \multirow{2}{*}{0.098} \\
\hline & Mean \pm SD & $3.31 \pm 0.253$ & $1.48+0.78$ & & \\
\hline \multirow{2}{*}{ Alpha feto-protein } & Range & $0.63-32.2$ & $0.83-20.1$ & \multirow{2}{*}{0.447} & \multirow{2}{*}{0.663} \\
\hline & Mean \pm SD & $4.27+5.52$ & $3.28+4.24$ & & \\
\hline \multirow{2}{*}{ Random blood sugar } & Range & 71-307 & 76-187 & \multirow{2}{*}{1.253} & \multirow{2}{*}{0.256} \\
\hline & Mean \pm SD & $97.2 \pm 27.8$ & $104.2 \pm 27.5$ & & \\
\hline
\end{tabular}

Table (6): Comparison between the studied groups as regard AAR, APRI, API, CDS, FIB-4 index, FibroQ index and Pohl score

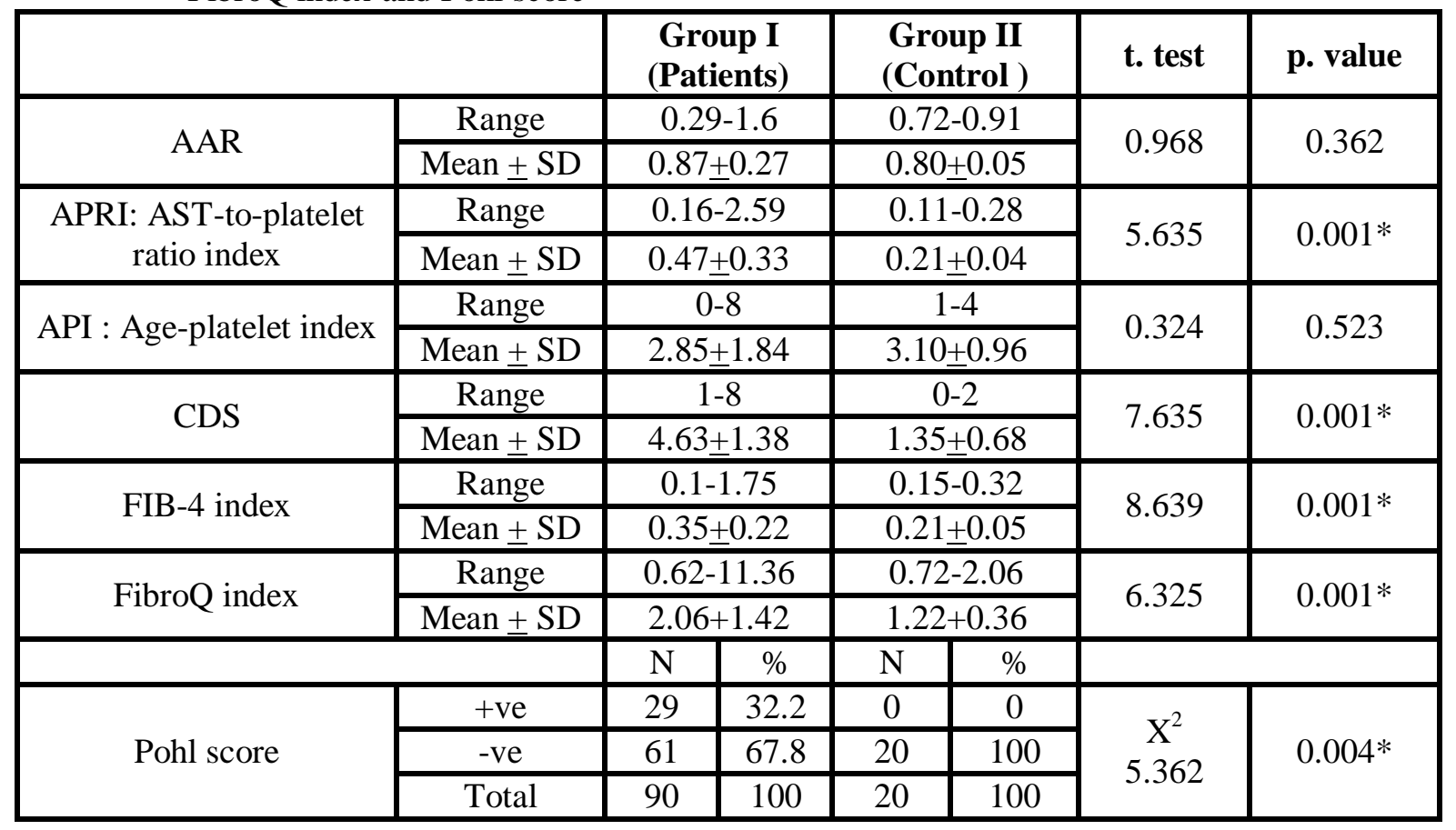


Table (7): Correlation between FibroQ and different variables

\begin{tabular}{|c|c|c|}
\hline & \multicolumn{2}{|c|}{ FibroQ index } \\
\hline & r. & P. value \\
\hline Sex & 0.236 & $0.025 *$ \\
\hline Age & 0.387 & $0.001 *$ \\
\hline AST(SGOT) & 0.077 & 0.473 \\
\hline INR & 0.365 & $0.001 *$ \\
\hline ALT(SGPT) & -0.215 & $0.042 *$ \\
\hline Platelets & -0.605 & $0.001 *$ \\
\hline AAR & 0.503 & $0.001^{*}$ \\
\hline APRI & 0.498 & $0.001 *$ \\
\hline API & 0.635 & $0.001 *$ \\
\hline $\mathrm{CDS}$ & 0.752 & $0.001 *$ \\
\hline Fib-4 index & 0.956 & $0.001 *$ \\
\hline Pohl score & -0.204 & $0.025^{*}$ \\
\hline Alkaline phosphatase & 0.523 & $0.001 *$ \\
\hline Serum albumin & -0.352 & $0.006^{*}$ \\
\hline Prothrombin time and control & -0.269 & $0.042 *$ \\
\hline Prothrombin activity & 0.302 & $0.028 *$ \\
\hline Alpha feto-protein & -0.241 & $0.030^{*}$ \\
\hline ANA titer by ELIZA & 0.056 & 0.598 \\
\hline Schistosomal AB by ELIZA & 0.269 & $0.012 *$ \\
\hline TSH & -0.046 & 0.667 \\
\hline HCV-RNA level (PCR) & 0.691 & $0.001 *$ \\
\hline $\mathrm{HB} \%$ & 0.001 & 0.992 \\
\hline RBCS & -0.104 & 0.331 \\
\hline WBCS & -0.233 & $0.027 *$ \\
\hline Mean platelet volume (mpv) & -0.165 & 0.120 \\
\hline Radom blood sugar & 0.275 & $0.009 *$ \\
\hline Creatinine & 0.011 & 0.917 \\
\hline Urea & -0.062 & 0.558 \\
\hline Total bilirubin & 0.138 & 0.193 \\
\hline Direct bilirubin & 0.204 & 0.054 \\
\hline
\end{tabular}

Table (8): Results of liver biopsy in group I (patients)

\begin{tabular}{|c|c|c|}
\hline Fibrosis & $\mathbf{N}$ & \% \\
\hline F1 & 10 & 11.1 \\
\hline F2 & 54 & 60.0 \\
\hline F3 & 22 & 24.4 \\
\hline F4 & 4 & 4.4 \\
\hline Total & 90 & 100.0 \\
\hline
\end{tabular}


Table (9): Correlation of histological fibrosis stages with different variables

\begin{tabular}{|l|c|c|}
\hline & $\begin{array}{c}\text { S rank correlation coefficient } \\
(\mathbf{9 5 \%} \mathbf{C I})\end{array}$ & P value \\
\hline Age $(\mathrm{yr})$ & $0.241(0.111-0.358)$ & 0.001 \\
\hline AST $(\mathrm{U} / \mathrm{L})$ & $0.165(0.061-0.310)$ & 0.002 \\
\hline ALT (U/L) & $-0.033(-0.142$ to 0.112$)$ & 0.003 \\
\hline PT INR & $0.311(0.210-0.414)$ & 0.005 \\
\hline PLT $(\times 103 / \mu \mathrm{L})$ & $-0.310(-0.410$ to -0.225$)$ & 0.007 \\
\hline Hb & $-0.140(-0.252$ to -0.041$)$ & 0.005 \\
\hline WBC & $-0.056(-0.144$ to 0.065$)$ & 0.141 \\
\hline Cr & $-0.127(-0.228$ to -0.033$)$ & 0.028 \\
\hline FT4 & $-0.141(-0.242$ to -0.053$)$ & 0.036 \\
\hline TSH & $0.071(-0.061$ to 0.174$)$ & 0.114 \\
\hline Bil(T) & $0.127(0.007-0.228)$ & 0.039 \\
\hline AAR & $0.320(0.219-0.432)$ & 0.002 \\
\hline APRI & $0.300(0.200-0.415)$ & 0.005 \\
\hline FibroQ & $0.435(0.313-0.515)$ & 0.001 \\
\hline FIB-4 & $0.420(0.310-0.512)$ & 0.001 \\
\hline CDS & $0.162(0.020-0.310)$ & 0.017 \\
\hline API & $0.323(0.217-0.418)$ & 0.001 \\
\hline Lok's model & $0.426(0.301-0.529)$ & 0.001 \\
\hline Pohl score & $0.112(0.015-0.247)$ & 0.001 \\
\hline
\end{tabular}

Table (10): Results of non invasive fibrosis tests in different fibrosis stages

\begin{tabular}{|l|c|c|c|c|}
\hline \multicolumn{1}{|c|}{ Score } & F1 & F2 & F3 & F4 \\
\hline AAR & $0.415 \pm 0.11$ & $0.611 \pm 0.21$ & $0.641 \pm 0.21$ & $0.752 \pm 0.20$ \\
\hline APRI & $1.214 \pm 1.02$ & $1.924 \pm 1.90$ & $2.147 \pm 1.20$ & $2.841 \pm 0.47$ \\
\hline FibroQ & $1.147 \pm 0.80$ & $2.517 \pm 1.61$ & $3.221 \pm 2.01$ & $3.624 \pm 0.41$ \\
\hline FIB-4 & $1.96 \pm 1.35$ & $2.56 \pm 2.03$ & $3.47 \pm 1.54$ & $3.963 \pm 1.29$ \\
\hline CDS & $4.93 \pm 1.41$ & $5.10 \pm 1.19$ & $5.37 \pm 1.13$ & $6.87 \pm 2.317$ \\
\hline API & $4.10 \pm 2.15$ & $5.17 \pm 2.14$ & $5.30 \pm 2.16$ & $6.74 \pm 1.49$ \\
\hline Lok's model & $0.29 \pm 0.24$ & $0.42 \pm 0.16$ & $0.45 \pm 0.47$ & $0.51 \pm 0.10$ \\
\hline Pohl score & $0.02+0.16$ & $0.03 \pm 0.11$ & $0.08 \pm 0.20$ & $0.74 \pm 0.15$ \\
\hline
\end{tabular}

Table (11): Diagnostic accuracy of simple fibrosis prediction tests for mild fibrosis (F1-F2)

\begin{tabular}{|l|c|c|c|c|c|}
\hline \multirow{2}{*}{} & \multicolumn{5}{|c|}{ F1, F2 } \\
\cline { 2 - 6 } \multicolumn{1}{c|}{} & Cut-off value & Sensitivity & Specificity & PPV & NPV \\
\hline APRI & $>1.5$ & 77.6 & 81.6 & 72.6 & 84.6 \\
\hline FibroQ & $>1.4$ & 86.0 & 79.6 & 75.4 & 90.6 \\
\hline FIB4 & $>1.8$ & 84.6 & 78.6 & 87.5 & 83.5 \\
\hline CDS & $>1.5$ & 78.2 & 81.4 & 82.3 & 85.4 \\
\hline API & $>2.3$ & 75.6 & 83.6 & 82.6 & 77.6 \\
\hline AAR & $>2.4$ & 77.4 & 63.6 & 72.6 & 89.6 \\
\hline Pohl score & $>1.4$ & 69.6 & 67.9 & 63.4 & 72.2 \\
\hline
\end{tabular}


Table (12): Diagnostic accuracy of simple fibrosis prediction tests for extensive fibrosis (F3-F4)

\begin{tabular}{|l|c|c|c|c|c|}
\hline \multirow{2}{*}{} & \multicolumn{5}{|c|}{ F3, F4 } \\
\cline { 2 - 6 } & Cut-off value & Sensitivity & Specificity & PPV & NPV \\
\hline APRI & $>1.6$ & 88.6 & 75.6 & 69.6 & 77.3 \\
\hline FibroQ & $>2.6$ & 84.9 & 79.6 & 68.7 & 78.3 \\
\hline FIB4 & $>2.4$ & 88.4 & 77.4 & 76.6 & 80.4 \\
\hline CDS & $>2.9$ & 90.4 & 83.9 & 77.2 & 80.6 \\
\hline API & $>3.7$ & 83.7 & 80.4 & 74.6 & 76.8 \\
\hline AAR & $>1.9$ & 76.5 & 73.6 & 81.2 & 76.5 \\
\hline Pohl score & $>2.8$ & 83.6 & 79.2 & 63.3 & 80.3 \\
\hline
\end{tabular}

\section{DISCUSSION}

Egypt has the highest prevalence of hepatitis $\mathrm{C}$ virus (HCV) infection in the world, affecting about $15 \%-25 \%$ of the population in rural communities [18,19]. $\mathrm{HCV}$ is one of the major causes of chronic liver diseases worldwide, which include inflammation, fibrosis and cirrhosis. Also, HCV is associated with increased morbidity and mortality in hepatocellular carcinoma [2022]. Although liver biopsy is expensive, requires hospitalization for at least 6-18 hours, invasive and carries a risk of complications with an associated morbidity rate between $0.3 \%$ and $0.6 \%$ and mortality rate of $0.05 \%$, it remains the gold standard for assessing liver histology [23, 24]. Also, limitations of liver biopsy include the underestimation of fibrosis stage as only $1 / 50000$ of the organ is removed [25] and the reported inter- and intra-observer variations rates of $10 \%$ $20 \%$ [26,27]. Serum markers of liver fibrosis offer a good alternative to liver biopsy for both patients and clinicians as they are less invasive, have practically no complications, little or no sampling errors and small observer related variations. Moreover, measurements may be performed repeatedly, thus, allowing for a dynamic monitoring of fibrosis [28].The present study showed that AST levels increase and platelet count decreases with fibrosis advancement and this is in agreement with Chun et al. [29] who Showed that severity of liver fibrosis was correlated significantly with an increase in AST level and a decrease in platelet count and that is called AST to platelet ratio index (APRI). The current study showed positive correlation between prothrombin time (PT) and fibrosis progression, which comes in agreement with Cadranel and Philippe [30] who said that PT was an accurate, cheap, and reproducible serum marker of extensive fibrosis, and they consider PT reflects liver function and constitutes a reliable marker of fibrosis progression and this result comes in disagreement with Coverdale et al. [31] who reported that there is no correlation between PT and fibrosis progression and advised not to rely on it. In the current study, there was a statistically significant thrombocytopenia with progressive fibrosis. This result came in agreement with Sherlock and Dooley [32] who reported that there was a decrease in platelet count due to hypersplenism. Also Peck-Radoslavljevic [33], showed that low platelet count is a valuable marker of advanced liver disease. The current study revealed significant correlation between HCV-RNA load as measured by quantitative PCR and both the grade of activity and fibrosis stage and this is in agreement with Kato et al. [34] who found significantly higher HCV RNA loads in patients with chronic active hepatitis and cirrhosis compared to those with chronic persistent hepatitis. In contrast, our results disagreed with the studies conducted by Lee et al. [35] and Saleem et al. [36] that showed no significant correlation between HCV RNA load as measured by quantitative PCR and both the grade of activity and fibrosis stage. In the current study, at a cutoff of AAR >2.4 to predict the presence of mild fibrosis, the sensitivity was $77.4 \%$, specificity was $63.6 \%$, PPV was $72.6 \%$, and NPV was $89.6 \%$ and at a cutoff of AAR $>1.9$ to predict the presence of extensive fibrosis, the sensitivity was $76.5 \%$,specificity was $73.6 \%$, PPV was $81.2 \%$ and NPV was $76.5 \%$. These results comes in disagreement with previous findings by Giannini et al. [37] who recommended an AAR value of $\geq$ 1 as a cutoff value for diagnosing extensive fibrosis and Ehsan et al. [38] who reported a cutoff value $(\geq 1.5)$ for diagnosing extensive fibrosis, with a sensitivity of $44 \%$ and a specificity of $91 \%$. Also Fouad et al. [39] found that the optimal cutoff AAR value for diagnosing cirrhosis was $\geq 1.2$, with a sensitivity of $46 \%$, specificity of $88.7 \%$ and PPV and NPV of $50 \%$ and $87.3 \%$, respectively. Park et al. [40] reported 
that AST/ALT > or $=1$ is highly specific but not diagnostic for the presence of cirrhosis in patients with chronic HCV infection and concluded that the ratio reflects the grade of fibrosis in these patients. In the current study, the cut off value for APRI that could predict mild liver fibrosis was $>1.5$ with a sensitivity $77.6 \%$, specificity $81.6 \%$, PPV $72.6 \%$, and NPV $84.6 \%$, while its cut off value that could predict extensive liver fibrosis was $>1.6$ with a sensitivity $88.6 \%$, specificity $75.6 \%$, PPV $69.6 \%$ and NPV $77.3 \%$. These results came in agreement with various studies proposed that APRI is a good index for estimating liver fibrosis stage. For example in a study that carried out by Lackner et al. [41] on HCV patients, area under the ROC curve (AUROC) was 0.740 for prediction of significant fibrosis and for prediction of cirrhosis, AUROC was 0.910 (according to Ishak score). Results from the current study revealed a significant correlation between APRI and both the stage of liver fibrosis and the grade of activity. The optimal cutoff APRI value for the diagnosis of extensive fibrosis was >1.6, which was not consistent with findings by Ichino et al. [42] and Ehsan et al. [38] who reported cutoff values of 1.3 and 1.5, respectively. Also our results comes in disagreement with Fouad et al. [39] who said that the optimal cutoff APRI value for the diagnosis of cirrhosis was $\geq 1.36$. In the current study, the cut off value for FIB-4 that could predict mild liver fibrosis was $>1.8$ with a sensitivity of $84.6 \%$, specificity $78.6 \%$, PPV $87.5 \%$ and NPV $83.5 \%$, while its cut off value that could predict extensive liver fibrosis was $>2.4$ with a sensitivity $89.4 \%$, specificity $57.4 \%$, PPV $71.6 \%$ and NPV $80.4 \%$. These results came in agreement with Yang et al. [43] who reported that FIB-4 index had a significant power for differentiation between patients with mild and significant fibrosis in nonalcoholic fatty liver disease $(0.24$ \pm 0.12 vs. $0.31 \pm 0.21, \mathrm{P}=0.010)$ and the AUROC of FIB4 was 0.810. They reported that FIB4 might be useful as a noninvasive hepatic fibrosis scores for predicting hepatic fibrosis in patients with NAFLD. The FIB-4was validated in a large cohort of HCV mono-infected patients in whom values $<1.45$ had a NPV of $94.7 \%$ to exclude severe fibrosis $(F 3-F 4)$ with a sensitivity of $74.3 \%$. A FIB-4 value higher than 3.25 , had a positive predictive value (PPV) of $82.1 \%$ with a specificity of $98.2 \%$ [44]. In the present study, we found a statistically significant correlation ( $P=0.001$ ) between positive Pohl score (AAR $\geq 1$, and platelet count $<150 \times 109 / \mathrm{L})$ and the presence of fibrosis. These findings supported the results of Pohl et al. [14], Lackner et al. [41] and Fouad et al. [39] who confirmed the diagnostic accuracy of the Pohl score in significant fibrosis and cirrhosis. The results of previous study by Hsieh et al. [45] which has included 237(135 male and 102 female) patients showed that Pohl score and CDS had high specificity but low sensitivity, and their AUCs were not statistically different from 0.5. In addition, FibroQ, FIB-4, and Lok's model showed the best performance characteristics. The AUCs for predicting significant fibrosis were $0.789,0.785$ and 0.768 , respectively. The AUCs for predicting extensive fibrosis were 0.728, 0.725 and 0.721 , respectively $[\mathbf{1 5 , 1 6 ]}$. In the current study, the cut off value for FibroQ that could predict mild liver fibrosis was $>1.4$ with a sensitivity of $86 \%$, specificity $79.6 \%$, PPV $75.4 \%$ and NPV $90.6 \%$, while its cut off value that could predict extensive liver fibrosis was $>2.3$ with a sensitivity $86.9 \%$, specificity $76.6 \%$, PPV $68.7 \%$ and NPV $76.3 \%$. These results came in agreement with Hsieh et al. [17] who showed that FibroQ has better accuracy than AAR and APRI. Using a cutoff value of the FibroQ score of $>1.6$, the presence of significant fibrosis could correctly be identified with a high accuracy (93\% PPV) in $92(65 \%)$ of the 140 patients. Also Hsieh et al. [17] showed that among patients with a FibroQ score of 0.6 or less, five of nine (55.6\%) did not have significant fibrosis. Among the 116 patients who had significant fibrosis, only four patients had FibroQ scores of 0.6 or less. Among patients with FibroQ scores of >1.6, 92 of 99 (92.9\%) had significant fibrosis and only seven patients without significant fibrosis were classified incorrectly. Together, using the FibroQ below the lower cutoff value (0.6) and above the higher cutoff value (1.6), 108 of the 140 patients (77.1\%) were identified correctly as with or without significant fibrosis. In this regard, these results were similar to that of APRI as described by Wai et al. [17].

\section{CONCLUSION}

The current study demonstrated that FibroQ, FIB-4, and Lok's model are simple methods that correlated well with the stages of fibrosis in patients with chronic hepatitis C. FibroQ showed a trend to be superior to the other modalities evaluated. Further prospective studies involving larger numbers of patients are needed to validate the usefulness of FibroQ in clinical practice.

Funding: None. 
Conflicts of interest: None.

Ethical approval: Approved.

\section{REFERENCES}

1. Wald O,Weiss ID,Galun E , Peled A. Chemokines in hepatitis $\mathrm{C}$ virus infection: pathogenesis, prognosis and therapeutics. Cytokine 2007; 39(1): 50-62.

2. Frank C, Mohamed MK, Strickland GT, Lavanchy D, Arthur RR, Magder LS et al.The role of parenteral antischistosomal therapy in the spread of hepatitis C virus in Egypt. Lancet 2000; 355(9207): 887-891.

3. Persico M, Persico E, Suozzo R, Conte S, de Seta M, L. Coppola L et al. Natural history of hepatitis $\mathrm{C}$ viruscarriers with persistently normal aminotrans-ferase levels. Gastroenterology 2000 ; 118(4): 760-764.

4. Seeff LB, Hoofnagle JH. National Institutes of Health consensus development conference: management of hepatitis C. Hepatology 2002; 36(5B): s1-s2.

5. Castéra L, Le Bail B, Roudot-Thoraval F, Bernard PH, Foucher J, Merrouche W et al. Early detection in routine clinical practice of cirrhosis and oesophageal varices in chronic hepatitis $\mathrm{C}$ : comparison of transient elastography (FibroScan) with standard laboratory tests and non-invasive scores. Journal of hepatology 2009 ; 50(1): 59.

6. Wong JB, Bennett WG, Koff RS, Pauker SG. Pretreatment evaluation of chronic hepatitis C: risks, benefits, and costs. JAMA 1998; 280: 20882093.

7. Bedossa $P$, Dargère $D$, Paradis V. Sampling variability of liver fibrosis in chronic hepatitis $\mathrm{C}$. Hepatology 2003; 38: 1449-1457

8. Akkaya O, Kiyici M, Yilmaz Y, Ulukaya E, Yerci O. Clinical significance of activity of ALT enzyme in patients with hepatitis $\mathrm{C}$ virus. World $\mathrm{J}$ Gastroenterol 2007; 13: 5481-5485 .

9. Lu SN, Wang JH, Liu SL, Hung $\mathrm{CH}$, Chen $\mathrm{CH}$, Tung HD et al. Thrombocytopenia as a surrogate for cirrhosis and a marker for the identification of patients at high-risk for hepato-cellular carcinoma. Cancer 2006; 107: 2212-2222.

10. Wai CT, Greenson JK, Fontana RJ, Kalbfleisch JD, Marrero JA, Conjeevaram HS. A simple noninvasive index can predict both significant fibrosis and cirrhosis in patients with chronic hepatitis C. Hepatology2003; 38:518-526.

11. Williams AL, Hoofnagle JH. Ratio of serum aspartate to alanine aminotransferase in chronic hepatitis. Relationship to cirrhosis. Gastroenterology 1988; 95: 734-739.

12. Bonacini M, Hadi G, Govindarajan S, Lindsay KL. Utility of a discriminant score for diagnosing advanced fibrosis or cirrhosis in patients with chronic hepatitis $\mathrm{C}$ virus infection. Am $J$ Gastroenterol1997; 92: 1302-1304.
13. Poynard T, Bedossa P. Age and platelet count: a simple index for predicting the presence of histological lesions in patients with antibodies to hepatitis C virus. METAVIR and CLINIVIR Cooperative Study Groups.J Viral Hepat 1997; 4: 199-208

14. Pohl A, Behling C, Oliver D, Kilani M, Monson $P$, Hassanein T. Serum aminotransferase levels and platelet counts as predictors of degree of fibrosis in chronic hepatitis $\mathrm{C}$ virus infection. $\mathrm{Am}$ J Gastroenterol2001; 96: 3142-3146

15. Sterling RK, Lissen E, Clumeck N, Sola R, Correa MC, Montaner J et al. Development of a simple noninvasive index to predict significant fibrosis in patients with HIV/HCV coinfection. Hepatology2006; 43: 1317-1325.

16. Cheung RC, Currie S, Shen H, Bini EJ, Ho SB, Anand BS et al. Can we predict the degree of fibrosis in chronic hepatitis $\mathrm{C}$ patients using routine blood tests in our daily practice?. J ClinGastroenterol 2008; 42: 827-834.

17. Hsieh YY, Tung SY, Lee IL, Lee K, Shen CH, Wei KL et al. FibroQ: an easy and useful noninvasive test for predicting liver fibrosis in patients with chronic viral hepatitis. Chang Gung Med J 2009; 32: 614-622.

18. Abdel-Wahab MF, Zakaria S, Kamel M, AbdelKhaliq MK, Mabrouk MA, Salama H et al. High seroprevalence of hepatitis $\mathrm{C}$ infection among risk groups in Egypt. Am J Trop Med Hyg 1994; 51: 563-567.

19. Frank C, Mohamed MK, Strickland GT, Lavanchy D, Arthur RR, Magder LS et al. The role of parenteral antischistosomal therapy in the spread of hepatitis C virus in Egypt. Lancet 2000; 355: 887-891.

20. Shaheen AA, Myers RP. Diagnostic accuracy of the aspartate aminotransferase-to platelet ratio index for the prediction of hepatitis C-related fibrosis: a systematic review.Hepatology2007; 46: 912-921.

21. Sebastiani G. Non-invasive assessment of liver fibrosis in chronic liver diseases: implementation in clinical practice and decisional algorithms. World J Gastroenterol 2009; 15:2190-2203

22. Lin ZH, Xin YN, Dong QJ, Wang Q, Jiang XJ, Zhan SH, SunY, Xuan SY. Performance of the aspartate aminotransferase to-platelet ratio index for the staging of hepatitis C-related fibrosis: an updated meta-analysis. Hepatology2011; 53:726736.

23. Poynard T, Imbert-Bismut F, Munteanu M, Messous D, Myers RP, Thabut D et al. Overview of the diagnostic value of biochemical markers of liver fibrosis (FibroTest, HCV FibroSure) and necrosis (ActiTest) in patients with chronic hepatitis C. CompHepatol2004; 3: 8.

24. Cadranel JF, Rufat P, Degos F. Practices of liver biopsy in France: results of a prospective nationwide survey. For the Group of Epidemiology 
of the French Association for the Study of the Liver (AFEF).Hepatology2000; 32: 477-481.

25. Wong JB, Koff RS. Watchful waiting with periodic liver biopsy versus immediate empirical therapy for histologically mild chronic hepatitis C.A cost-effectiveness analysis. Ann Intern Med 2000; 133: 665-675.

26. Colloredo G, Guido M, Sonzogni A, Leandro G. Impact of liver biopsy size on histological evaluation of chronic viral hepatitis: the smaller the sample, the milder the disease. JHepatol2003; 39: 239-244.

27. Regev A, Berho M, Jeffers LJ, Milikowski C, Molina EG, Pyrsopoulos NT et al. Sampling error and intraobserver variation in liver biopsy in patients with chronic $\mathrm{HCV}$ infection. Am $J$ Gastroenterol2002; 97: 2614-2618.

28. Zhou Kand Lu LG. Assessment of fibrosis in chronic liver diseases. Journal of Digestive Diseases; 2009, 10(1):7-14.

29. Chun T,Wai J ,Greenson KA. Simple Noninvasive Index Can Predict Both Significant Fibrosis and Cirrhosis in Patients With Chronic Hepatitis C . Hepatology 2003; 38( 2):518-26.

30. Cadranel JF , Philippe M . Prothrombin index decrease: a useful and reliable marker of extensive fibrosis. Eur. J.Gastroenterol. Hepatol 2002; 14(10): 1057-1059.

31. Coverdale SA,Samarasinghe DA, Lin R,Kench J, Byth K, Khan MH et al. Changes in antipyrine clearance and platelet count, but not conventional liver tests, correlate with fibrotic change in chronic hepatitis $\mathrm{C}$ : value for predicting fibrotic progression. Am. J. Gastroenterol. 2003; 98(6): 1384-1390.

32. Sherlock S, Dooley J : Anatomy and function; Biopsy of the liver and hepatic cirrhosis. In Diseases of the liver and Biliary system "11th Edition", Blackwell Sc. Publ., Oxford, London, Edinburgh, 2002, (1): 1-16; (3): 37-44 and (21): 365-377.

33. Peck-Radoslavljevic M. Hypersplenism. Eur J Gastroenterol Hepatol ; 2001 , 13: 317-323.

34. Kato N, Yokosuka O, Hosoda K, Ito Y, Ohto M, Omata M.Quantification of hepatitis $\mathrm{C}$ virus by competitive reverse transcription-polymerase chain reaction: increase of the virus in advanced liver disease. Hepatology1993; 18: 16-20.

35. Lee YS, Yoon SK, Chung ES, Bae SH, Choi JY, Han JY et al. The relationship of histologic activity to serum ALT, HCV genotype and HCV RNA titers in chronic hepatitis C. J Korean Med Sci2001; 16: 585-591.

36. Saleem N, Mubarik A, Qureshi AH, Siddiq M, Ahmad M, Afzal S, Hussain AB, Hashmi SN. Is there a correlation between degree of viremia and liver histology in chronic hepatitis C? J Pak Med Assoc 2004; 54: 476-479.

37. Giannini E,Risso D, Botta F, Chiarbonello B, Fasoli A, Malfatti F et al. Validity and clinical utility of the aspartate aminotransferase-alanine aminotrans-ferase ratio in assessing disease severity and prognosis in patients with hepatitis C virus-related chronic liver disease. Arch Intern Med 2003; 163: 218-224.

38. Ehsan N, Tawfik Badr MT, Raouf AA, Badra G. Correlation Between Liver Biopsy Findings and Different Serum Biochemical Tests in Staging Fibrosis in Egyptian Patients with Chronic Hepatitis C Virus Infection. Arab J Gastroenterol2008; 9:7-12.

39. Fouad SA, Esmat S, Omran D, Rashid L, Kobaisi $\mathrm{MH}$. Noninvasive assessment of hepatic fibrosis in Egyptian patients with chronic hepatitis C virus infection. World J Gastroenterol 2012; 18(23): 2988-2994.

40. Park GJ, Lin BP, Ngu MC, Jones DB, Katelaris $\mathrm{PH}$. Aspartate aminotransferase: alanine aminotransferase ratio in chronic hepatitis $\mathrm{C}$ infection: is it a useful predictor of cirrhosis? $J$ Gastroenterol Hepatol 2000; 15:386-90.

41. Lackner C, Struber G, Liegl B, Leibl S, Ofner P, Bankuti C,Bauer B, Stauber RE. Comparison and validation of simple noninvasive tests for prediction of fibrosis in chronic hepatitis C. Hepatology 2005; 41: 1376-1382.

42. Ichino N, Osakabe K, Nishikawa T, Sugiyama H, Kato M, Kitahara $\mathrm{S}$ et al. A new index for noninvasive assessment of liver fibrosis. World $J$ Gastroenterol 2010; 16: 4809-4816.

43. Yang H R, Kim H R, Kim M J, Ko J S, Seo J K. Noninvasive Parameters and hepatic fibrosis scores in children with nonalcoholic fatty liver disease. World J Gastroenterol 2012; 7, 18(13): 1525-30.

44. Vallet-Pichard A, Mallet V, Nalpas B, Verkarre V, Nalpas A, Dhalluin-Venier V, Fontaine H, Pol S. FIB-4: an inexpensive and accurate marker of fibrosis in HCV infection. Comparison with liver biopsy and fibrotest.Hepatology2007; 46:32-36

45. Hsieh YY, Tung SY, Lee K, Wu CS, Wei KL, Shen $\mathrm{CH}$, Chang TS , Lin YH. Routine blood tests to predict liver fibrosis in chronic hepatitis C. World J Gastroenterol 2012; 18(8): 746-53.

Peer reviewer: Tarik Zaher, Professor of Tropical Medicine and Hepatogastroenterology, Faculty of Medicine, Zagazig University, Egypt. Editor: Mohamed Emara, Lecturer of Tropical Medicine and Hepatogastroenterology , Faculty of Medicine, Zagazig University, Egypt. 